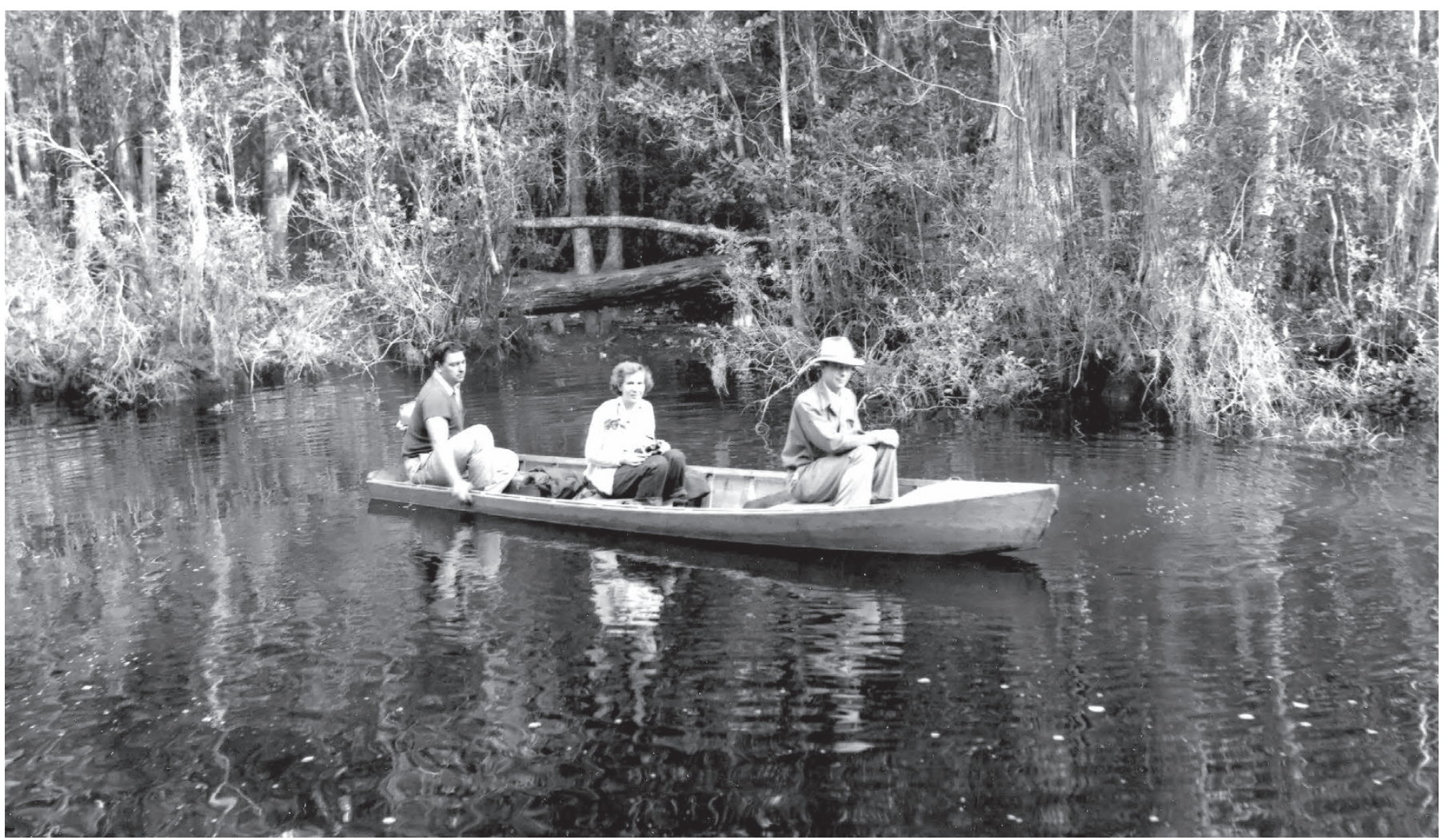

George Fell (right) and Barbara Fell (centre) scouting in Okefenokee Swamp, between Georgia and Florida, with a guide.

ENVIRONMENT

\title{
Hero of local conservation
}

\section{Stuart Pimm learns about the man behind the world's largest conservation body.}

$\mathrm{I}$ 1951, the Nature Conservancy was launched in Washington DC, reborn from its prototype, the Ecologists' Union. Its first, barely paid, director was George Fell. With his fellow naturalist and wife, Barbara, Fell had bankrolled the fledging organization with US\$300. Today, the conservancy is one of the world's biggest conservation bodies, with annual revenues of about $\$ 1$ billion in 2014 . Fell, meanwhile, seems to have fallen out of history: there is little mention of him online, even on the charity's website. Yet, as Arthur Pearson explains in his thought-provoking biography Force of Nature, Fell articulated a vision of biodiversity protection that is as current today as it was nearly 70 years ago.

As Pearson relates, much of Fell's career was inauspicious. At school, he was an average student. As an adult, he was uncompromising, single-minded and prone to picking political fights he would not win. He lost jobs with regularity. His genius, however, was in advocating nature conservation where it mattered the most. Ultimately, the Fells understood natural history and the special places where rare and unique species

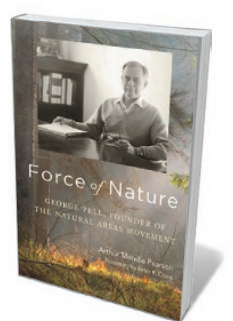

Force of Nature: George Fell, Founder of the Natural Areas Movement ARTHUR M. PEARSON University of Wisconsin Press: 2017. inspires a passion for protecting large tracts of wilderness. For Fell, it was Illinois, and the defining experience was looking for plants - especially ferns - in what little remained of its natural habitats. During their courtship, the Fells became concerned about local environmental degradation, "driving around the state in search of remnant natural areas".
Illinois, the 'prairie state', lies east of the Mississippi River, yet its original grasslands were more typical of the West. In the early nineteenth century, the state had 10 million hectares of prairie; by 1978, there were fewer than 2,300. The state's population of the iconic greater prairie chicken (Tympanuchus cupido) plummeted from 30,000 in 1940 to fewer than 2,000 by 1960 (today, there are no more than 200). Illinois did not get the break of eastern US forests, which partially recovered from the late nineteenth century onwards as people abandoned poorquality land and moved west to plough the prairies. Nor was it spared like the deserts and mountains of the far west, which support few people. Illinois is a tough place to conserve biodiversity.

During Fell's tenure at the conservancy, he and Barbara believed that its future must be as a confederation of state chapters. Each would remain powerful in defending its own priorities, but as a federation the national office would have supremacy. Board members disagreed and, in a divisive election in 1958, Fell lost his bid to become 
president. Moreover, against his strenuous objections, the conservancy's governors allocated general-purpose contributions in their entirety to the national office. The board preferred to cherry-pick what it perceived as more-glamorous national efforts, and stacked its membership with representatives from the US east coast.

The Fells returned to Rockford, Illinois, that year, intent on building local conservation. Here, Fell founded the Natural Land Institute, which so far has protected almost 6,500 hectares in northern Illinois. A larger achievement was to create a state-wide system of nature reserves, which demanded state involvement and a protracted and difficult campaign. Fell's tenacity was essential: he wanted the state to pay, but he also wanted substantial autonomy to prevent any politically motivated takeover. There was tension with existing state bodies over the right to recreational use of the land.

Despite the setbacks, the state (in the form of the Illinois Nature Preserves Commission) protected almost 2,000 hectares in its first year. This was more than the Nature Conservancy did in its first decade. Fell set an aggressive agenda to counter the pressures to create areas predominantly for recreation. The land he saw protected spans the state.

Today, the conservancy's land investments are concentrated in rich counties in the US northeast, even though the southeast has many more endemic species, and other areas (such as Illinois) represent unique conservation challenges. Fell's greatest legacy remains the conservancy's nationwide state chapters and the regional conservation they achieve. At the Green Swamp Preserve in North Carolina, my state chapter protects the threatened Venus flytrap (Dionaea muscipula), a species famous for being actively carnivorous - and less well known for the vulnerability of its tiny geographic range.

The quest to save sensitive regions and their species can brook no compromise to satisfy national leaders or to placate those who seek state-wide populist agendas. Neither did the Fells.

Stuart Pimm is professor of conservation at the Nicholas School of the Environment at Duke University in Durham, North Carolina, and directs the non-profit organization SavingSpecies, www.savingspecies.org. e-mail:stuartpimm@me.com

\section{CLARIFICATION}

After Nature went to press, the name of the exhibition reviewed in the Books \& Arts article 'World of webs' by Philip Ball (Nature 543, 314; 2017) was changed to How to Entangle the Universe in a Spider's Web.

\section{Books in brief}

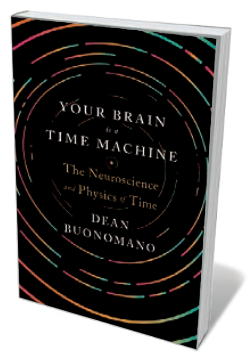

Your Brain Is a Time Machine: The Neuroscience and Physics of Time Dean Buonomano W. W. NoRTON (2017)

Apparently elastic and possibly illusory, time is a puzzle to physicists and neuroscientists alike. Dean Buonomano straddles the divide, invoking cutting-edge theory and research as he wrestles with the often glaring mismatch between physical and 'felt' time. The result is immensely engaging, exploring why we use spatial metaphors (such as a long day) when talking about time; why presentism (the theory that only the present is real) is upheld in neuroscience but plays underdog in physics; and how not just consciousness and free will, but also space-time and relativity, can be parsed in neuroscience.

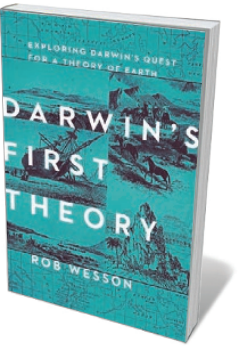

Darwin's First Theory: Exploring Darwin's Quest for a Theory of Earth Rob Wesson PEGasus (2017)

For this adventurous study of Charles Darwin's contribution to geology, seismologist Rob Wesson traded computer screen for trenching shovel to trace the Victorian icon's far-flung fieldwork. Wesson trekked from Wales to Patagonia and journeyed along the watery route of HMS Beag/e, interweaving Darwin's observations of lava beds and erratic boulders with vivid accounts of his own research on the sites, and interpolations of science. A wonderful evocation of Darwin's great theory of subsidence and uplift, the substrate of his later, explosive discovery of evolution.



Governing Global Health: Who Runs the World and Why? Chelsea Clinton and Devi Sridhar OXFORD UNIVERSITY PRESS (2017) Global public-health governance can seem tortuously complex. Specialists in the field Chelsea Clinton and Devi Sridhar pierce the haze, usefully focusing on players old and new, from the World Health Organization to public-private partnerships such as Gavi, the Vaccine Alliance, that involve collaboration between governments and social entrepreneurs. This is smart research with nuanced conclusions, for instance stressing the need for broader on-theground change - strong health-care systems, socio-economic equity and climate-change policy — if interventions are to fully root.



\section{An American Sickness}

Elisabeth Rosenthal PENGUIN (2017)

The US health-care system pivots on blatant profiteering, argues journalist (and former physician) Elisabeth Rosenthal in this bold, insightful, well-researched analysis. Brick by brick — from insurance to research - Rosenthal dismantles the edifice to discover where the billions in bills end up, and boils her research down to ten 'rules' that dominate the dysfunction, such as the lack of fixed prices for medical tests. She also outlines a range of suggestions for the fight against unneeded treatments and stratospheric fees, from comparison shopping for drugs to insisting on itemized bills.

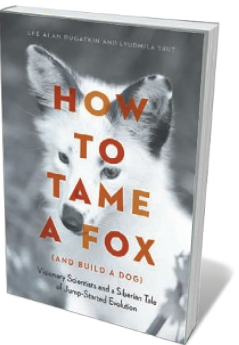

\section{How to Tame a Fox (and Build a Dog)}

Lee Alan Dugatkin and Lyudmila Trut UNIVERSITY OF CHICAGO PRESS (2017) In 1959, in the frigid depths of a Siberian winter, two Soviet geneticists launched a singular experiment. Dmitri Belyaev and Lyudmila Trut (who co-wrote this account with Lee Alan Dugatkin) set out to replicate wolf domestication by selecting silver foxes from fur farms for 'tameness traits', and breeding them. This compressed evolution has spawned 56 generations of tame foxes - with spotted coats and an affinity for humans - and uncovered findings such as relative disparities in the animals' gene expression. Barbara Kiser 